\title{
PRODUKSI KEDELAI DENA 1 (Glycine max (L) Merrill.) DI BAWAH TEGAKAN KELAPA SAWIT
}

\author{
Kamsia Dorliana Sitanggang, Cici Yustika Rini \\ Program Studi Agroteknologi Sekolah Tinggi Ilmu Pertanian Labuhanbatu \\ Jln. SM. Raja No 126 A Aek Tapa Labuhanbatu Sumatera Utara \\ Email : kamsiasitanggang@gmail.com
}

\begin{abstract}
The objectives of this research is to know the production of Dena-1 varieties under and without oil palm tree (TM 8) using peat soil media in polybags. The results showed that there were differences in the production of Dena 1 soybean varieties planted under palm and open areas using peat soil media, where soybeans planted under oil palm (TM8) were unable to produce only reach vegetative growth, while soybeans were planted in the open yields average number of pods of 5-6 plant pods, average number of seeds of 10 crop seeds and average seed weight of 1.31 grams of planting.
\end{abstract}

Keywords: crop, peat, soybean

\section{PENDAHULUAN}

Upaya peningkatan luas areal tanam kedelai di Indonesia terkendala penyusutan luas lahan akibat adanya alih fungsi lahan dari sektor pertanian ke sektor non pertanian. Salah satu upaya untuk meningkatkan luas lahan pertanian, khususnya kedelai adalah melalui optimalisasi lahan perkebunan dengan memanfaatkan lahan diantara tegakan tanaman perkebunan yang masih muda (Ghosh et al. (2009), Gao et al. (2010) dan Echarte et al. (2011).

Kedelai merupakan salah satu tanaman yang sering ditanam dalam pola tumpang sari, akan tetapi sebagai tanaman sela penanaman kedelai dengan sistem tumpang sari mengalami beberapa kendala,diantaranya adalah penaungan oleh tajuk tanaman utama (Atman 2009).Cahaya matahari merupakan salah satu faktor lingkungan utama yang paling penting mengatur fotosintesis dan berdampak pada kelangsungan hidup tanaman, pertumbuhan, dan adaptasi (Zhang et al., 2003). Kualitas dan kuantitas cahaya matahari dapat memicu terjadinya perubahan morfologi seperti tahan, menghindari, atau melawan naungan (Kurepin et al., 2007).

Salah satu upaya yang telah dilakukan oleh tim peneliti dari BALITKABI Malang adalah dengan mengeluarkan kedelai yang toleran terhadap naungan sampai $50 \%$ yaitu varietas Dena-1. Kedelai varietas Dena-1 merupakan salah satu varietas unggul yang dapat ditanam di bawah tegakan tanaman perkebunan, hutan tanaman industri (HTI) yang masih muda atau tumpangsari dengan tanaman pangan lain. Kedelai Dena-1 memiliki tinggi tanaman sekitar $59 \mathrm{~cm}$, bentuk biji lonjong dengan potensi hasil 2,89 ton/ha dan rata - rata hasil 1,69 t/ha (Susanto \& Novita 2011). Sebahagian besar area perkebunan di Indonesia terdiri dari tanah gambut. Gambut merupakan 
hasil pelapukan bahan organik seperti dedaunan, ranting kayu, dan semak dalam keadaan jenuh air dan dalam jangka waktu yang sangat lama. Penelitian ini bertujuan untuk melihat perbedaan produksi kedelai Dena-1 yang ditanam dibawah tegakan sawit dan area terbuka dengan menggunakan media tanah gambut.

\section{METODE PENELITIAN}

Benih yang digunakan adalah benih kedelai varietas Dena-1 yang didatangkan langsung dari BALITKABI (Balai Penelitian Tanaman Aneka Kacang dan Umbi) -Malang. Benih diambil sebanyak 80 biji, dimana 40 biji ditanam pada media gambut dibawah tegakan sawit, dan 40 lagi ditanam pada media gambut area terbuka (tanpa naungan).

Penanaman benih kedelai dilakukan setelah penataan polibag ke lahan percobaan. Jarak tanam yang digunakan adalah 0,5 x 0,5 m. Data yang diamati antara lain: (1) Jumlah polong pertanaman (polong), (2) Jumlah biji per tanaman (butir), (3) Berat biji per tanaman (g). Data hasil percobaan dipresentasikan dalam bentuk grafik.

\section{HASIL DAN PEMBAHASAN}

\section{Jumlah polong pertanaman}

Jumlah polong tertinggi pertanaman terdapat pada tanaman yang ditanam di area terbuka (tanpa naungan) pada tanaman ke 18 yaitu menghasilkan 11 polong, sedangkan kedelai yang ditanam di antara tegakan sawit TM 8 (bawah naungan) tidak dapat berproduksi (Gambar 1). Tanaman yang ditanam dibawah tegakan hanya mampu bertahan hidup tanpa menghasilkan.

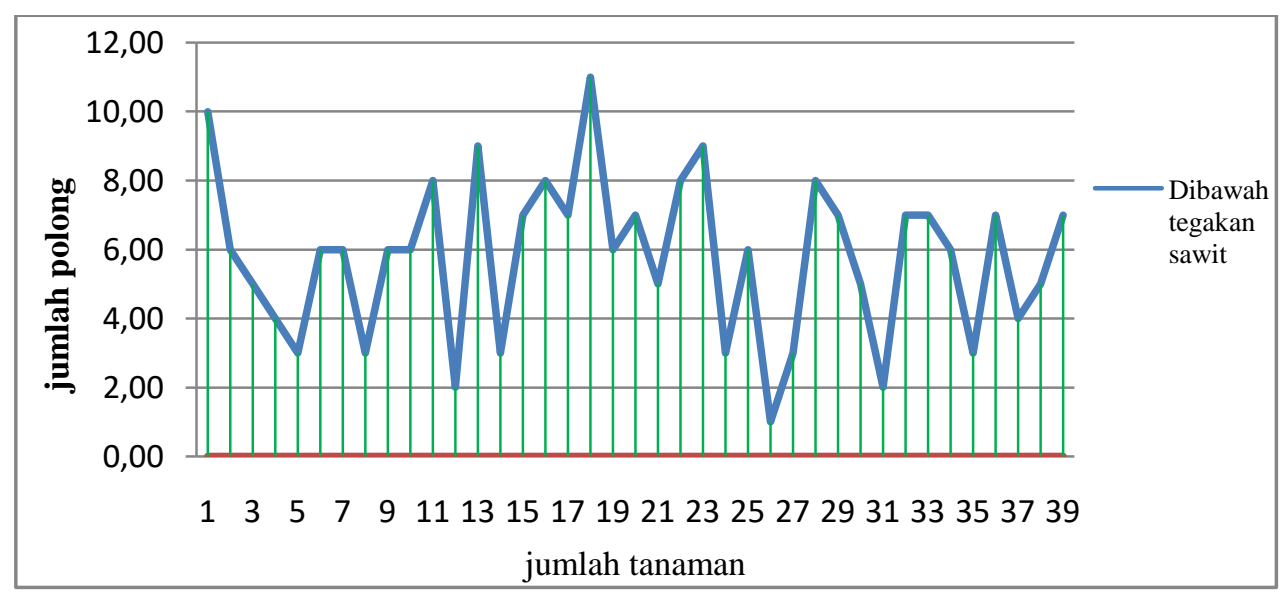

Gambar 1. Grafik jumlah polong kedelai pada media gambut diantara tegakan dan terbuka

Rata-rata produksi kedelai yang ditanam pada media gambut tanpa naungan (area terbuka) menghasilkan rata rata jumlah polong sebesar 6 polong pertanaman, sedangkan kedelai yang ditanam di bawah tegakan sawit tidak mampu berproduksi. Salah satu kemungkinan penyebab kedelai yang ditanam di antara tegakan kelapa sawit (bawah naungan) tidak mampu berproduksi adalah karena kemungkinan umur tanaman kelapa sawit yang sudah mencapai 12 tahun (TM 8) sehingga naungan sudah di atas $50 \%$ yang mengakibatkan media sering basah dan berair, sementara dilihat dari deskripsi kedelai Dena 1, bahwa kedelai Dena 1 
hanya mampu bertahan sampai naungan $50 \%$.

Karamoy (2009) menyatakan bahwa cahaya sangat besar pengaruhnya dalam proses fisiologi, seperti fotosintesis, pertumbuhan, perkembangan, pembukaan dan penutupan stomata, pergerakan tanaman dan perkecambahanyang nantinya akan berpengaruh pada produksi.Faktor lain yang mengakibatkan tanaman tidak menghasilkan polong kemungkinan karena media tanam yang di gunakan adalah media gambut dengan $\mathrm{pH}$ 5. Kondisi tanah gambut yang masam ini disebabkan akibat akumulasi bahan organik dan tanah dalam lingkungan anaerob, sehingga banyak terbentuk asam-asam organik yang nantinya dapat mempengaruhi ketersediaan hara didalam tanah (Riswandi, 2001).

\section{Jumlah biji pertanaman (butir)}

Penanaman kedelai varietas Dena-1 pada media gambut dibawah tegakan sawit dan area terbuka juga menunjukkan hasil yang berbeda pada pengamatan jumlah biji per tanaman (Gambar 2).

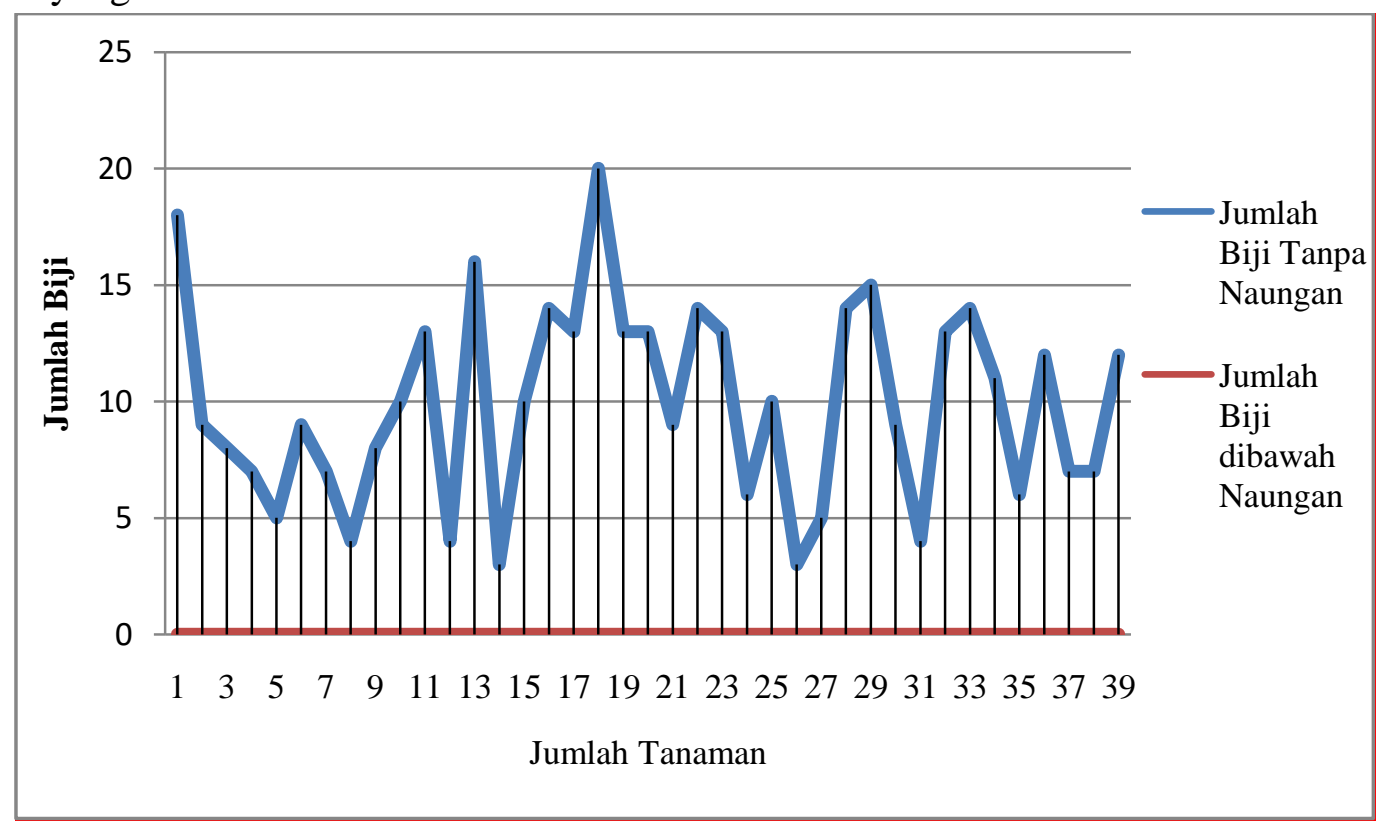

Gambar 2. Grafik Jumlah Biji Pertanaman

Perbedaan jumlah biji sangat kontras antara perlakuan penanaman kedelai pada media gambut dibawah tegakan sawit dan area terbuka. Jumlah biji tertinggi terdapat pada kedelai yang ditanam di area terbuka (tanpa naungan) yaitu sebanyak20 biji,dengan rata-rata 10 biji pertanaman, berbeda dengan kedelai yang ditanam di bawah naungan tidak dapat tidak dapat berproduksi.

Naungan akan menyebabkan terhambatnya laju fotosintesis yang akhirnya berpengaruh terhadap hasil jumlah biji kedelai per tanaman. Hal ini sesuai dengan pernyataaan Adisarwanto (2005) bahwa tanaman kedelai yang tumbuh pada lingkungan ternaungi pada fase generatif akan mengalami penurunan aktivitas fotosintesis sehingga alokasi fotosintesis ke organ reproduksi menjadi

berkurang dan menyebabkan jumlah biji menjadi lebih sedikit dibandingkan pada kondisi tanpa naungan. Faktor lain kemungkinan penyebab produksi (jumlah 
biji yang rendah dengan rata rata 10 biji pertanaman, adalah karena kandungan $\mathrm{P}$ dan $\mathrm{K}$ yang tersedia pada tanah gambut tergolong sangat rendah. Rendahnya $\mathrm{P}$ dan $\mathrm{K}$ pada tanah gambut diduga karena lahan gambut merupakan hasil akumulasi bahan organik yang belum terdekomposisi secara sempurna dan menyebabkan lahan gambut miskin unsur hara $\mathrm{P}$ dan $\mathrm{K}$, maka dari itu unsur hara $\mathrm{P}$ dan $\mathrm{K}$ pada tanah gambut sangat diperlukan terhadap perubahan kesuburan tanah (Agus \& Subiksa, 2008).

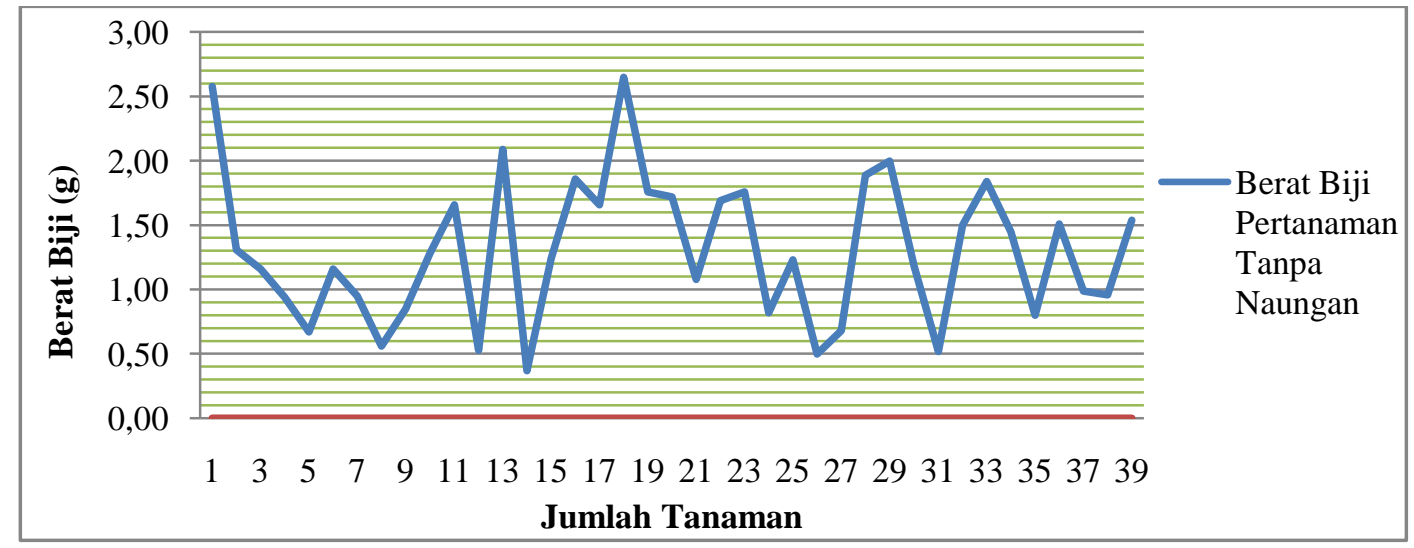

Gambar 3. Berat Biji Pertanaman

Berat biji kedelai tertinggi pertanaman terdapat pada perlakuan tanpa naungan (area terbuka) tanaman ke 18 yaitu memiliki berat sebesar 2,65g/tanaman. Jika dilihat dari segi ratarata, maka setiap tanaman kedelai yang ditanam tanpa naungan menghasilkan ratarata berat biji 1,30 g/tanaman sedangkan dibawah naungan kedelai yang tidak dapat berproduksi.

Tanaman yang tidak diberi naungan (ditanam di tempat terbuka) mampu bertahan hidup sampai menghasilkan produksi biji. Hal ini disebabkan tanaman menerima lebih cukup

\section{Berat Biji Pertanaman}

Perbedaan berat biji kedelai yang ditanam diantara tegakan sawit dan area terbuka juga menunjukkan perbedaan yang sangat kontras (Gambar 3). 
pengurangan intensitas cahaya sebesar $50 \%$ akan menurunkan jumlah polong isi dengan nilai tengah $72 \%$ dari kontrol (kondisi intensitas cahaya 100\%). Untuk mendapatkan hasil optimal, tanaman kedelai membutuhkan curah hujan antara 100-200 mm/bulan (Warintek 2008). Curah hujan yang sangat tinggi selama penelitian, diduga menyebabkan kedelai menerima pasokan air yang berlebihan, sehingga hal ini berpengaruh terhadap komponen hasil kedelai. Interaksi antara naungan dan varietas menghasilkan bobot biji kering per tanaman.

\section{KESIMPULAN}

Terdapat perbedaan jumlah polong, jumlah biji, dan berat biji yang sangat kontras pada kedelai yang ditanam di bawah tegakan sawit (kelapa sawit TM 8) dan tanpa naungan. Rata - rata jumlah polong pertanaman sebanyak 5-6 polong, sedangkan jumlah biji dengan rata-rata produksi sebanyak 10 biji pertanaman, dan rata-rata berat biji pertanaman adalah 1,30 gram, sedangkan kedelai yang ditanam di bawah naungan tidak berproduksi.

\section{DAFTAR PUSTAKA}

Adisarwanto. 2005. Budidaya Kedelai dengan Pemupukan yang Efektif dan Pengoptimalan Peran Bintil Akar.Penebar Swadaya . Jakarta.
Agus F, Subiksa IG. 2008. Lahan Gambut: Potensi untuk Pertanian dan Aspek Lingkungan. Balai Penelitian Tanah. Bogor. 6 hal.

Atman. 2009. Strategi Produksi Kedelai di Indonesia.Jurnal Ilmiah Tambua. 8(1):39-45.

Echarte L, AD. Maggiora, D. Cerrudo, VH.Gonzalez, P. Abbate, A. Cerrudo, VO. Sadras, P. Calvino. 2011. Yield Response to Plant Density of Maize and Sunflower Intercropped with Soybean. Field Crops Research. 121. 423-429.

Gao Y, AW. Duan, XQ. Qiu, JS. Sun, JP. Zhang, H. Liu, HZ. Wang. 2010. Distribution and Use Efficiency of Photosynthetically Active Radiation in Strip Intercropping of Maize and Soybean. Agronomy Journal. 102: 1149-1157.

Ghosh PK, AK. Tripathi, KK. Bandyopadhyay, MC.Manna. 2009. Assessment of Nutrient Competition and Nutrient Requirement in Soybean/Sorghum Intercropping System. European Journal of Agronomy. 31(1): 4350.

Karamoy L.2009. Relationship Between Climate and Soybean Growth.Soil Environment. 7(1):65-68

Kurepin LV, JRN. Emery, RP. Pharis, DM. Reid. 2007. Uncoupling Light Quality from Light Irradiance Effects in Helianthus annuus Shoots: Putative Roles for Plant Hormones in Leaf and Internode Growth.J. Exp. Bot. 58:2145-2157.

Riswandi. 2001. Kajian Stabilitas Gambut Tropika Indonesia Berdasarkan Analisis Kalangan Karbon Organik Sifat Fisik, Kimia dan komposisi 
Bahan Gambut. [Disertasi]. Program Pasca Sarjana Institut Pertanian Bogor.

Sopandie D, Trikoesoemaningtyas, Handayani T, Jufri A, Takano T. 2003. Adaptability of Soybean to Shade Stress: Identification of Morphological Responses. Di dalam: [tidak disebutkan], editor.

The 2nd Seminar toward Harmonization between Development and EnvironmentalConservation in Biological Production; 2003 15-16 Feb; Tokyo University, Tokyo.

Sopandie D, Trikoesoemaningtyas, Khumaida N. 2006. Fisiologi, Genetik, dan Molekuler Adaptasi Terhadap Intensitas Cahaya Rendah: Pengembangan Varietas Unggul Kedelai sebagi Tanaman Sela.Laporan Akhir Penelitian Hibah Penelitian Tim Pasca Sarjana-HPTP Angkatan II Tahun 2004-2006. Lembaga Penelitian dan Pemberdayaan Masyarakat. Institut Pertanian Bogor. 159 hlm.
Susanto GWA, Novita N. 2011. Pengenalan dan Karakteristik Varietas Unggul Kedelai.Malang (ID): Balitkabi.

Wahyu G, Sundari T. 2010. Penampilan Varietas Unggul Kedelai di Lingkungan Naungan Buatan. Malang (ID): Balitkabi.

Warintek Warung Informasi dan Teknologi Bantul. 2008. Budidaya pertanian [internet]. [diunduh 2013 Mei 8]. Tersedia pada: http://warintek.bantulkab.go.id/web .php? $\mathrm{mod}=$ basisdata $\&$ kat $=1 \&$ sub $=$ $2 \&$ file $=59$.

Zhang J, DL. Smith, W. Liu, X. Chen, W.Yang. 2011. Effects of Shade and Drought Stress on Soybean Hormones and Yield of Main-stem and Branch. African Journal ofBiotechnology. 10(65):1439214398. 